catalog designed to perform definite functions. There will still be rules, but they will be fewer, let us hope, and less inviolate, the attention of the cataloger being focused primarily on the objectives to be achieved.

For the administrator, the new code may mean some reduction in the cost of cataloging, although this is doubtful. It will certainly check for a time, however, additional increases in costs that might have otherwise accrued from the further elaboration of "bibliographical" techniques.

For the cataloging profession as a whole, it should mean unification again on the basis of an acceptable standard of descriptive cataloging, with an immediate revival of cooperative enterprise. There is every reason to believe that all or most of the libraries which have recently departed from Library of Congress practice will find it possible and desirable to adopt the new code, not only because it will do what they have already been trying to do, but also because the new code will enable them to do it better.

In preparing this new code, the Processing Department of the Library of Congress has assumed a great responsibility. If the work is finished with the same display of imagination, reason, and courage which has distinguished it thus far, the responsibility will have been nobly discharged. We now have the principles; we eagerly await the code.

Raynard C. Swank

\title{
Resources for Research
}

The First Century of the John Carter Brown Library, a History with a Guide to the Collections. By Lawrence C. Wroth. Providence, R.I., The Associates of the John Carter Brown Library, 1946. vi, 88p. William Andrews Clark Memorial Library, Report of the First Decade, 1934-1944. [Edited by Lawrence Clark Powell.] Berkeley and Los Angeles, Calif., University of California Press, 1946. vii, 78p. The psychology of custodianship of rare books has undergone certain rather profound but inevitable changes in recent decades. Administrators of special collections for literary and historical research have become increasingly active in carrying out a responsibility which is at least twofold, and "preservation" and "availability for scholarly use" are companion requirements in today's scheme of service for the library that finds itself possessed of valuable books and manuscripts. This is not to infer that librarians of the past have not understood the nature of their responsibility but only that the means of meeting it have not always been at hand. It has been necessary for administrators to devise standards-often complicated and always costly to apply-whereby the two objectives could be brought into accord. And before that could be done, it had to be realized that the objectives are not irrevocably at opposite poles from each other. Curators of the watchdog type had to be persuaded that books are, for the most part, quite sturdy objects and not fragile things with which no scholar, no matter how righteous his need, is to be trusted. They had to be shown that their cause would be strengthened and their function made more comprehensible if the sterner rules were applied only to those books that are truly fragile-illuminated manuscripts, books printed on brittle paper, historic bindings, and the like. On the other hand, the scholar has had to submit to reading under supervision. No longer may he stuff, a rare colonial tract in his pocket, to be mulled over in the comfort of a private office or cubicle. That is the prerogative of ownership, and the books and manuscripts contained in a research library are not the property of any one scholar but of all scholars. There is simply no choice in the matter.

The two progress reports under consideration here relate to the John Carter Brown and William Andrews Clark libraries, and furnish excellent examples of the modern approach to the problems of administering large and important collections of rarities, near rarities, and basic resources. In addition, a third facet of the responsibility of custodianship is brought forcibly to the forefront of attention-that of assuring constant and intelligent growth. Both discussions begin by tracing the origins of the respective collections which were founded and fostered as the personal hobbies of the men whose names 
they bear but which have since become identified with great universities. Each treatise then undertakes to describe in general terms the content of the collection with which it deals and to discuss the preferable directions that future development should take. The fact that the reports show clearly what the availability of the collections means to the relevant fields of scholarship, with emphasis on the larger usefulness which such collections acquire when they are combined with research library facilities, cannot fail to encourage and point up further benefactions on the part of private collectors.

The two reports are welcome additions to a notable file of predecessors, which include such useful titles as The Whys and Wherefores of the William L. Clements Library (1930); The Huntington Library Collections (Bulletin No. I, I93I); The University [Chicago] Libraries (1933); The Library of Harvard University (1934, 4th ed.); Handbook of the Newberry Library (1938); A Faculty Survey of the University of Pennsylvania Libraries (1940); The Pierpont Morgan Library, Review of Activities ... . 1936 through 1940 (1941); The John Crerar Library, 1895-1944 (1945); The Library Resources of the University of North Carolina (1945); and The Yale Collections (1946). The above is by no means intended to be a definitive list; there are doubtless many similar studies that have escaped this reviewer's notice. In fact, a general bibliography of the literature describing the resources of university and research libraries in the United States would be gratefully received by scholars everywhere.

\section{Physical Differences}

It is perhaps nothing amiss that the reports of the Brown and Clark libraries achieve success along quite different routes as regards physical format and textual treatment. In space, a continent separates Providence from Los Angeles, and in time, almost a century separates the inceptions of the two collections. Lawrence C. Wroth, librarian of the John Carter Brown Library since 1923, concludes that, although Mr. Brown's ultimate decision to concentrate on "the large-scale acquisition of Americana" cannot be dated certainly much before 1845 , his essential interest in book collecting can be traced to the early years of the nineteenth century. Cora Edgerton Sanders, curator of the Clark Memorial Library until her retirement in 1943, records that Mr. Clark "began assembling his library about seventeen years before his death," which occurred on June 14, 1934.

The differences in time and space are nowhere so strongly evident as in the typographical treatment of the two volumes. Mr. Wroth's essay is clothed with the quiet dignity which critics and printers alike accept as the unvarying hallmark of the Merrymount Press; the discussion of the Clark library is printed in that lively and colorful style which has come to be identified (even this somewhat nostalgic ex-patriot from the Pacific Coast wonders on what grounds) as the "California School of Printing." To dismiss thus lightly the very estimable typographical achievements of Messrs. Bianchi and Farquhar as exemplified in these volumes is perhaps less than justice, but one inevitably expects the best of printing from those master craftsmen. The books now under discussion bolster such expectations.

Mr. Wroth presents his report of the collection in his charge in three main sections: "A Century of Purpose," containing a brief history of the library; "An Analysis of the Collections;" and "The Work of the $\mathrm{Li}$ brary." The first part, as the subtitle suggests, traces the development of the great repository of early Americana from the first decades of the nineteenth century. Of special interest is the discussion of the formation, around the middle of the century, of Mr. Brown's policy of collecting only books of American interest printed before 1801 . "Throughout the Library's changes of status," writes Mr. Wroth, "as the possession of two later private owners and of Brown University, that boundary, though for reasons different from those which moved Mr. Brown, has never been changed." Elsewhere he writes what should be engrossed on the walls of every collector's library-"There is no virtue in age of itself, but continuity and steadily maintained purpose are excellent things in the formation of book collections. Inevitably libraries possessing these attributes are made up of books and groups of books which newer institutions must seek in vain." No one could have written that statement with better evidence at his beck than $\mathrm{Mr}$. 
Wroth has in the treasures of the John Carter Brown Library-many of them unique, far more of them forever beyond the budgetary reach of less foresighted libraries.

Part II, "An Analysis of the Collections," comprises "a conspectus of the principal categories which make up the collection, attempting appraisal of each of these by comment based upon experience in their practical utilization and by a statistical comparison of their contents with the totals found in standard catalogues and bibliographies." The library now contains about thirty thousand books, including bibliographical aids. In the section devoted to "Pre-Discovery Science and Geography" are to be found some three hundred works from the presses of Aldus and his descendants, which, in the opinion of $\mathrm{Mr}$. Wroth, embody "texts in which the thoughts and imagination of the ancient world are set forth with medieval and Renaissance commentary." For the "Period of Discovery and Exploration, I492-I550," there are some three hundred titles, including 50 per cent of the entries in Harrisse's standard bibliography of the period, plus forty-five titles and editions not listed by Harrisse.

\section{Latin American Titles}

Titles concerned with Latin American history and description are abundant, numbering about ten thousand and including some nineteen hundred items that were printed in the Western Hemisphere. There are seventythree titles printed in Mexico City from 1544-1600, comprising about 31 per cent of the 232 titles listed by Medina and believed to be "as large as any group in that category now existing in a public or private library in Europe or America." Nineteen of thirtytwo imprints produced in Lima before 1604 are present in the Brown library, and more than 50 per cent of the listed Brazilian works issued before 1800 . "We feel that these works combine with our Spanish-American sources to form a contribution to the history of America almost unrivalled in its completeness."

Early United States sources are provided in great abundance. The Southeast is represented by some 450 titles, the Spanish Southwest by 198 of $34 \mathrm{I}$ noticed in Wagner's bibliography, and for New France, Louisiana, and the French West Indies the proportion of Brown holdings against standard lists is invariably from 50 to 80 per cent of the totals.

"No department of the Library is more satisfactory to the student than the section on British America," writes Mr. Wroth, and gives the figures to show why that is so. Without exception, the same high percentage of known titles is to be found on the Brown library shelves. To continue further in this vein would be tiresomely repetitious, and the interested student is herewith referred to Mr. Wroth's discussion for the figures relating to Brown holdings in the literature of the American Revolution, the Constitution, western expansion, native American languages, church history, etc. One more significant set of statistics should be noted, however. Of all American imprints before 1800 listed in the Evans bibliography, the Brown library has 7382 , or 21 per cent of the total, placing that library in a class with the American Antiquarian Society, and the Congressional, New York Public, and Huntington libraries.

The third section of the book, "The Work of the Library," is in many respects the most interesting, for in it $\mathrm{Mr}$. Wroth discusses in general terms the direct contribution of the John Carter Brown Library to the world of scholarship. That contribution takes definite forms: in bibliographical study of the collections by the faculty and staff; in service to local and visiting students; in correspondence with distant students; in exhibitions and addresses; and in the publication and photographic services. These are all carefully described and the reader is left with the feeling that there is immense justice and promise in Mr. Wroth's closing words: "even while acclaiming our age and long tradition, while enumerating our possessions or boasting our strength in one or another category, we still hold heartily to the conviction that without service all these things are vanity. ... At the beginning of its second century, the John Carter. Brown Library is settling into its stride."

The report of the William Andrews Clark Library was prepared under the able editorship of Lawrence Clark Powell, director of libraries at the University of California at Los Angeles. With an enthusiastic and active faculty and staff to draw upon, Dr. Powell 
followed the plan adopted in 1940 for the survey of the University of Pennsylvania Libraries. The report is a symposium, with each major strength of the Clark library the subject of special study by the authority best qualified to judge it. Thus the historical background of the collection is discussed by those who helped develop it and interest the founder in placing it in the care of the young university: Ernest Carroll Moore, former provost and vice president of the university; Edward Augustus Dickson, chairman of the southern committee of the board of regents; Cora Edgerton Sanders, Mr. Clark's librarian, I90I-03, 1908-34, and curator of the Clark Memorial Library until 1943; and Robert D. Farquhar, the architect of the beautiful building on West Adams Boulevard that houses the fast-growing collection.

\section{English Drama to $\mathbf{I 7 0 0}$}

"English Drama to 1700 " is the subject of an essay by Hugh G. Dick, assistant professor of English in the university, who points out that the library's Shakespeare collection ranks no lower than fourth among those in American universities. There are excellent resources for the study of Shakespeare's contemporaries and close followers, but the principal strength for the period is in dramatic works from 1640 to 1700 . No more than representation has been sought for Renaissance literature, because of the close proximity of the Huntington collections, but preeminence in Restoration drama is the goal of an active acquisitions program. Dr. Dick looks toward virtual completeness in that field within the next decade.

"The Age of Dryden" is the subject of a discussion by Sigurd B. Hustvedt. Mr. Clark's interest in Dryden inevitably extended to that poet's predecessors and contemporaries, especially those in France. That broadening of scope has had a strong influence on the university's recent program of expansion, which is now "to concentrate attention upon Dryden and to his contemporaries, under a rather flexible definition of literary forms and merits." "In such a program," continued Prof. Hustvedt, "the period would have somewhat elastic measurements, so as to include Milton at the beginning, Swift and Defoe at the end. . . The Dryden thus to take shape would be no recluse in a garret, but a literary man in a world of letters." Some notion of the strength of the framework on which this acquisitions program is to be built may be had from the fact that of 197 Dryden items listed by Wing, 173 are in the Clark library.

\section{The Eighteenth Century}

"The Eighteenth Century" is discussed by Edward N. Hooker, who notes that "the strength of the Library holds until about 1735, after which date the entries in the chronological catalogue become notably fewer." There are several strong representations, chief among which are those of Swift and Pope (the latter being the object of careful searching during the past decade), Addison and Steele, Rowe and Congreve, John Gay, and many lesser literati.

"Music and Musical Literature" is treated by Walter H. Rubsamen, assistant professor of music. Mr. Clark's extensive collection of orchestral music was bequeathed to the Los Angeles Public Library, but a notable group of musical reference books, full and miniature scores of standard orchestral compositions, operas, and chamber music, and a small collection of letters and manuscripts of eminent musicians were included in the Clark library. Around this nucleus the university is building a reference library, including standard bibliographies, representative serial publications, and collected editions. Considerable stress has been laid on the acquisition of original musical works issued from 1600 to 1800 .

\section{Nineteenth-Century Holdings}

"The Library's holdings in the nineteenth century," writes Franklin P. Rolfe, "represent largely the interests of the donor and seldom approach completion in any category." The notable exception is the distinguished collection of Wildeiana, of which a special catalog was compiled by Robert Ernest Cowan and the founder. The collection includes a selective group of manuscripts and letters, among which is the correspondence written by Wilde from Reading Gaol to his friends, Robert Ross and More Adey. Other nineteenth-century authors are represented to a lesser degree, although the works of the romantic writers, Byron, Shelley, and Keats, are present in some abundance, and certain Victorians (the Brownings, Tennyson, Mor- 
ris, Fitzgerald, Thackeray, Dickens, and Stevenson) are fairly strong.

Lindley Bynum, special assistant to the president, describing the holdings in western Americana, notes that the Montana collection, purchased in 1924 , contains nearly two thousand bound volumes, nearly three thousand pamphlets, magazines, excerpts, and the like, as well as numerous maps, pictures, unbound newspapers, books of clippings, letter files, and legal papers. The collection was notably strengthened in 1939 by the purchase of the Willard S. Morse library of Bret Harte material. "Thus," concludes Mr. Bynum, "although the western Americana in the Clark library should be regarded as supplemental to the western materials in the University Library, in at least two fields of Montana history and Bret Harte it may be used as a source."

\section{Fine Printing}

One further facet of the Clark library is to be noticed, that of "Fine Printing," which is discussed by $\mathrm{H}$. Richard Archer, now in charge of the library. Mr. Clark, he tells us, was more than just a collector of fine books. $\mathrm{He}$ was "so much interested in fine printing that he would select from his collection some book of which he was especially fond, see that it was properly edited, and have it reprinted." In one instance, at least, his editors failed him; it in no respect detracts from the memory of this generous philanthropist to recall that at his behest and expense the Wise forgery of the famous "Reading Sonnets" was reproduced in careful facsimile.

Mr. Clark's collection of the Kelmscott and Doves presses is virtually complete, as is that of the work of his favorite among western printers, John Henry Nash. Other modern presses and certain early ones are represented by typical specimens. For the practical side of the graphic arts, there is good coverage in printing practice, type founding, bookselling, binding, illustration, descriptive bibliography, and related topics. Since the library has become the charge of the university, reference books on the graphic arts have more than doubled in number.

The William Andrews Clark Library is a young one, and it is the property of a young university. One predominating characteristic of youth is the tendency toward growth, and in this the Clark library is no exception. At the time of the death of its founder in 1934 it numbered eighteen thousand volumes. It has nearly doubled in size in the intervening decade. As Dr. Powell's report stresses, that growth has not been haphazard and uncontrolled but carefully planned and fostered to bring to it the maximum of scholarly usefulness, in accord with the ideas of the founder as they were expressed both in the deed of gift and in the way in which he himself developed his collection. That procedure might well serve as a model for librarians.-Roland Baughman.

\section{Implications of Armed Services Educational Programs}

Opinions on Gains for American Education from Wartime Armed Services Training. By M. M. Chambers. A Preliminary Exploratory Report for the Commission on Implications of Armed Services Educational Programs. Washington, D.C., American Council on Education, 1946. vii, $78 \mathrm{p}$.

Utilizing Human Talent. Armed Services Selection and Classification Procedures. By Frederick B. Davis for the Commission on Implications of Armed Services Educational Programs. Washington, D.C., American Council on Education, 1947. ix, $85 \mathrm{p}$.

Audio-Visual Aids in the Armed Services. Implications for Àmerican Education. By
John R. Miles and Charles R. Spain for the Commission on Implications of Armed Services Educational Programs. Washington, D.C., American Council on Education, 1947. xi, 96p.

About two years ago the American Council on Education received a grant of $\$ 150,000$ from the Carnegie Foundation and the General Education Board for a study "to find effective means of evaluating military experience for its potential significance to civilian institutions and to facilitate the understanding and adoption of those features of the military and educational programs which will improve education and training in civilian life."1

1 Zook, George F. Educational Record 27:26r, July 1946 . 